\title{
Effects of corundum in the development of structural, mechanical and tribological properties of raw materials for the manufacture of structural products
}

\author{
(Efeitos do coríndon no desenvolvimento de propriedades \\ estruturais, mecânicas e tribológicas das matérias-primas \\ para a fabricação de produtos estruturais)
}

\author{
L. Cely Illera ${ }^{1 *}$, J. Cely Niñón ${ }^{2}$ C. V. Cely Illera ${ }^{3}$ \\ ${ }^{1}$ Universidad Francisco de Paula Santander, Departamento de Ingeniería Industrial, CP 540003, Colombia \\ ${ }^{2}$ Universidad Francisco de Paula Santander, Departamento de Ingeniería de Sistemas, Colombia \\ ${ }^{3}$ BT Global Services, Colombia
}

\begin{abstract}
Improving the technological properties of a ceramic product without affecting its aesthetic quality is a daily challenge of the regional ceramic companies. To achieve this objective, analyzes were performed on an illitic-kaolinitic clay by adding corundum as an additive. The corundum content varied from $5 \%$ to $20 \%$ by weight with a particle size of less than $75 \mu \mathrm{m}$, being able to obtain products with low porosities and high mechanical resistance. This research is part of a series of studies carried out on an argillaceous raw material from the region of Norte de Santander (Colombia). The influence of the corundum content on the technological properties was evaluated. The results showed that corundum, when mixed with traditional raw materials, offers the conditions to be used as an additive in the production of ceramic products with increases of up to $67 \%$ in mechanical strength and a reduction of porosity of $46 \%$, which can contribute to the development of value-added ceramic products for use in other technological applications.
\end{abstract}

Keywords: corundum waste, water absorption, abrasion, flexural strength, tribological behaviour.

Resumo

Melhorar as propriedades tecnológicas de um produto cerâmico sem afetar sua qualidade estética é um desafio diário das empresas regionais de cerâmica. Para atingir este objetivo, foram realizadas análises em uma argila ilítica-caulinítica com adição de 5\% a $20 \%$ em massa de coríndon com tamanho de partícula inferior a $75 \mu \mathrm{m}$, obtendo produtos com baixa porosidade e alta resistência mecânica. Esta pesquisa é parte de uma série de estudos realizada em uma matéria-prima argilosa da região do Norte de Santander (Colômbia). Foi estudado o efeito do teor de coríndon nas propriedades tecnológicas. Os resultados mostraram que o coríndon, quando adicionado a matérias-primas tradicionais, pode ser usado como um aditivo na manufatura de produtos cerâmicos com aumentos de até $67 \%$ na resistência mecânica e redução de porosidade de 46\%, o que pode contribuir para o desenvolvimento de produtos cerâmicos com valor agregado para uso em outras aplicações tecnológicas.

Palavras-chave: resíduo de coríndon, absorção de água, abrasão, resistência à flexão, comportamento tribológico.

\section{INTRODUCTION}

Nowadays the search for better properties in the manufacture of traditional ceramics and the development of technology has led the industry to explore techniques that produce products with better functionalities, generating not only a large amount of waste and industrial byproducts but also an increased pollution in the world where we live, conditioning our environment. The transformation of clayey raw materials into construction products is not exempt from this problem because this is one of the processes that causes more pollution during its production cycle, not only in the manufacturing stages but also in the quality controls of the

*leonardocely@ufps.edu.co same ones, especially in those controls where industrial materials are used that are discarded after each analysis and in which most of the time there are no records of where they end up, as they are simply disposed of in the rubbish like any ordinary waste $[1,2]$.

It is for this reason that this type of research is carried out in order to be able to minimize to the maximum those pollution problems that are generated during the manufacturing cycle in an industrial process, since the final disposal of materials of this type is not a solution due to the possibility of generating undesirable materials for the environment. An environmentally correct solution that is being studied all over the world is the incorporation of these industrial waste in different raw materials, in this case in a clay body of laminar minerals such as illite and kaolinite 
accompanied by quartz and high iron and potassium oxide content [3], which was mixed with corundum (aluminum oxide) of particle size less than $75 \mu \mathrm{m}$ generated in the surface abrasion resistance test for glazed tiles [4]. This work aimed to evaluate the influence of the incorporation of up to $20 \%$ of corundum in the clay and its response in the raw part, its dry characteristics and the structural, mechanical and tribological properties, at higher temperatures than the typical ones in the manufacture of ceramic products seeking not only other uses other than the production of bricks but also opening other process windows in this industrial area in the region currently devalued, as well as finding another final disposal of this contaminated material.

\section{MATERIALS AND METHODS}

Materials: the raw materials used in this research were a clay from the municipality of Zulia, Norte de Santander (Colombia) from the Guayabo formation, with red tonality, plastic texture and an illite-kaolinite structure accompanied by quartz and oxides, such as potassium oxide, generally used for the manufacture of bricks and tiles (this raw material was studied in a previous work [3]), and a residue generated in the surface abrasion resistance test for glazed tiles, with a particle size less than $75 \mu \mathrm{m}$. The waste used was pure corundum, $99 \%$ according to the specifications of the standard ISO 10545-7, before being used for the development of the research it was sieved by 200 mesh (75 $\mu \mathrm{m})$, to ensure cleanliness and size. The characterization of the material is not exposed because it is pure material, in addition the important thing regarding this paper is not the characterization of raw materials but the influence of corundum on clay raw materials and the effects on their properties; both raw materials were initially dried at $110{ }^{\circ} \mathrm{C}$ before the representative samples were separated by quartet.

Methods: in order to determine the influence of corundum in the structural, mechanical and tribological development of a clay material, a number of formulations were made, for the preparation of powders and specimens to test humidity and pressing pressure; both clay and corundum were quantified by weight percentage, because regional companies make their formulations in this way [5]; the variation was 5\%, $10 \%$ and $20 \%$ by weight of corundum, and these were referenced as M5, M10 and M20, respectively, throughout the investigation and a sample of pure clay M0 was used to allow the comparison of results. Each formulation was prepared by wet milling in a laboratory alsing mill (Gabbrielli Technol.), taking the retained sieve of $63 \mu \mathrm{m}$ (230 mesh) as a parameter for grinding time; this is frequently used in the region to determine the clay fraction of the material and estimate the time for the development of wet milling. The slip was subjected to convection drying in an electric oven (Gabbrielli Technol.) at $110 \pm 5^{\circ} \mathrm{C}$ and the pressing powder was prepared with a moisture of $0.060 \pm 0.005 \mathrm{~kg}$ water $/ \mathrm{kg}$ ss, as mentioned in [6]. They were formed in a laboratory press with rectangular mold (Gabbrielli Technol.), prismatic probes of $110 \times 55 \times 7 \mathrm{~mm}$, at a pressure of $240 \mathrm{kgf} / \mathrm{cm}^{2}(23.5 \mathrm{MPa})$.
Specimens of each formulation and the M0 were then taken to perform the dilatometric test on a dilatometer (Dil 402 $\mathrm{C}$, Netzsch) to observe the influence of the corundum on the thermal expansion curves of the samples. This analysis was developed with a heating rate of $10^{\circ} \mathrm{C} / \mathrm{min}$ up to 1000 ${ }^{\circ} \mathrm{C}$, without heating soaking. The remaining samples were dried in an electric oven at $110 \pm 5^{\circ} \mathrm{C}$ for a period of $6 \mathrm{~h}$ in order to achieve equilibrium in residual moisture. They were then fired in a muffle oven (Gabbrielli Technol.) maintaining the heating rate of $10^{\circ} \mathrm{C} / \mathrm{min}$ at two maximum temperatures of 1200 and $1250{ }^{\circ} \mathrm{C}$ without soaking; the cooling of the samples was performed inside the furnace after shutdown; this experimental design was performed at temperatures higher than those frequently used in the region (900 to $1100{ }^{\circ} \mathrm{C}$ ) in order to observe the development of the material in other applications different from those used in traditional processes. In addition, the clay material was already studied at these temperatures in a previous work [3]; in each of the conditions (wet, dry and cooked), length and mass were determined.

Both, M0 and the formulations, were characterized physically (shrinkage, mass loss, bulk density and postpressed expansion) as well as technologically determining structural property (open porosity), mechanical (flexural strength) and tribological (deep abrasion) tests. They were carried out in triplicate in different specimens to study the homogeneity of the samples tested and for the test methods the respective standards for each property were followed. The physical characterization was initiated with the calculation of shrinkage [7], mass loss, bulk density and post-press expansion using a vernier caliper (Mitutoyo), a digital scale (Adventurer, Ohaus, $1500 \mathrm{~g}$ capacity and sensitivity of 0.01 g) and a mercury meter (Gabbrielli Technol.). The structural property was measured by the water absorption test by the boiling method leaving the specimens impregnated in boiling water for $2 \mathrm{~h}$ according to ISO 10545-3 [8]. The mechanical characterization was carried out by the flexural strength test using a pressure gauge (Crometro, Gabbrielli Technol.) by applying a loading speed of $1.0 \pm 0.2 \mathrm{MPa} / \mathrm{s}$ following the procedure of ISO 10545-4 [9]. Finally, the tribological property was determined by the wear resistance by calculating the length left by the constant pressure of a rotating disk of a $200 \mathrm{~mm}$ diameter and an abrasive material on the surface of the specimen at a rotation speed of $75 \mathrm{rpm}$ (the development of testing was performed by wearing the specimens during 150 turns), according to ISO 10545-6 [10].

\section{RESULTS AND DISCUSSION}

Influence of the corundum on the thermal expansion of the pieces: the clay used was a material of red tonality and of illitic-kaolinite composition with predominance of the illitic structure and abundant quartz in its crystalline structure [3], which affect the variations of size (thermal expansion) during its firing cycle and can generate some internal problems in the structure of the material; hence, the importance of studying this type of thermal expansion, 
which can generate defects such as distortions, problems of orthogonality, planarity and parallelism of their sides, etc., which are detrimental to the final properties of the material [11]. Fig. 1 shows the dilatometric curves of the samples; the development of this analysis was performed from room temperature up to $1000{ }^{\circ} \mathrm{C}$ to observe the initial behavior of the material because it is at this temperature range where most of the reactions occur that should be controlled when the material is sintered at high temperatures [12]. All the curves presented the same behavior with slight differences in M0, which presented a curve a little more upwards in comparison with the others. It was observed that M20 visibly reduced the slope of its curve, possibly due to the refractory property of the additive.

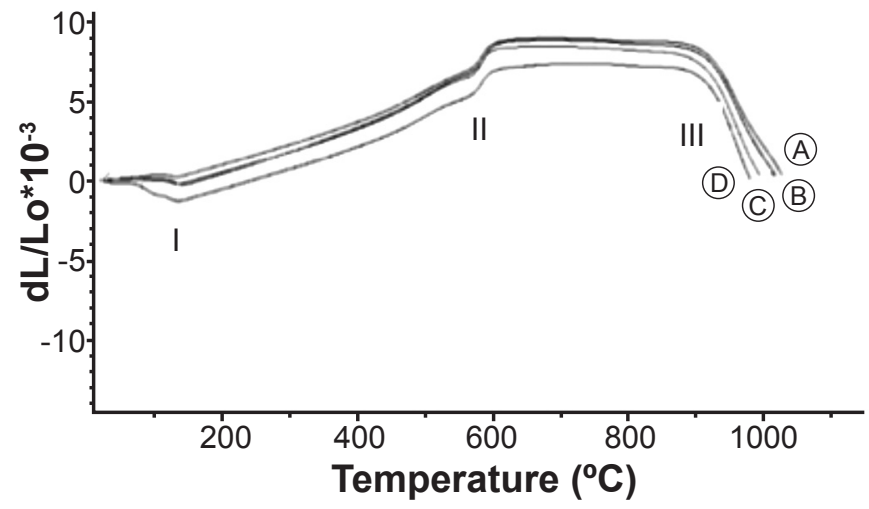

Figure 1: Dilatometric curves of the samples: A (M0), B (M5), C (M10), and D (M20).

[Figura 1: Curvas dilatométricas das amostras: A (M0), B (M5), C (M10) e D (M20).]

A short rectilinear initial section was observed which was interrupted when reaching peak $\mathrm{I}$ in the range between 100 and $200{ }^{\circ} \mathrm{C}$ (Fig. 1); this contraction was due in all cases to the removal of residual molding water and is characteristic of materials with the presence of illite structure. It is detailed in the coefficients of expansion (Table I) that decreased as the percentage of corundum increased, and this generates a decrease in the tensions by the contraction that occurs in this phase of the process generating a better behavior during its cycle of cooking as detailed below. Following this point, another straight section with a progressive increase in the slope up to $600{ }^{\circ} \mathrm{C}$ (point II) started; it is in this region where the allotropic quartz change takes place, the most serious turning point of the entire cycle of cooking because this is where the greatest defects occur in traditional ceramic products. As it can be seen, the coefficients of expansion between 500 and $600{ }^{\circ} \mathrm{C}$ (Table I) were reduced with an increase in the amount of the additive, controlling the high percentage of $\mathrm{SiO}_{2}$ containing in the pure sample (curve with higher slope and higher coefficient); this is an important aspect of the firing of a ceramic body. As it is known the control of a physical change as strong as the allotropic change of quartz is, where most fissures are generated, brings many benefits that is why the effect of corundum is important to reduce this coefficient, because not only it is possible to control the formation of microcracks generated in this phase of the process, but also it makes possible to work at higher temperatures with higher liquid phase content, which densify the material better and consequently increase its mechanical resistance [13, 14]. Finally, above $600{ }^{\circ} \mathrm{C}$ a plateau was produced in the curves until reaching $950^{\circ} \mathrm{C}$ (point III); then, the contraction was initiated and the softening of the material was indicated. It was observed that increasing the corundum reduced the expansion, displacing the zone of the first great contraction at higher temperatures and with a lower slope causing a slow and gradual decrease of the dimensions up to $1000{ }^{\circ} \mathrm{C}$, improving the cooking at high temperatures and increasing the structural, mechanical and tribological properties, as is shown later. Furthermore, it is generally known that ceramic materials having lower coefficients of thermal expansion exhibit higher resistance to thermal shock, despite their low ductility $[12,15]$.

Table I - Coefficient of thermal expansion. [Tabela I - Coeficiente de expansão térmica.]

\begin{tabular}{ccc}
\hline Formulation & $\alpha_{100-200}\left(10^{-7}{ }^{\circ} \mathrm{C}^{-1}\right)$ & $\alpha_{500-600}\left(10^{-7}{ }^{\circ} \mathrm{C}^{-1}\right)$ \\
\hline $\mathrm{M} 0\left(0 \mathrm{wt} \% \mathrm{Al}_{2} \mathrm{O}_{3}\right)$ & 63.1 & 310.9 \\
$\mathrm{M} 5\left(5 \mathrm{wt} \% \mathrm{Al}_{2} \mathrm{O}_{3}\right)$ & 47.4 & 293.8 \\
$\mathrm{M} 10\left(10 \mathrm{wt} \% \mathrm{Al}_{2} \mathrm{O}_{3}\right)$ & 34.2 & 292.1 \\
$\mathrm{M} 20\left(20 \mathrm{wt} \% \mathrm{Al}_{2} \mathrm{O}_{3}\right)$ & 28.8 & 281.0 \\
\hline
\end{tabular}

Properties of shaped parts: during the manufacturing process of the specimens, the moisture and the pressing pressure were kept constant; this was carried out in a hydraulic press and as shown in Table II the mixtures showed a decrease up to $7.11 \%$ post-press expansion with respect to $\mathrm{M} 0$; also, none of the formulations exceeded the $0.8 \%$ limit value of this parameter to generate possible defects obtaining a better control in the elastic energy that is stored in the piece after removing it from the socket of the mold, which is generated by exerting the pressure to compact and mold, depending on the geometry of the same [16]; this is an excellent behavior because by controlling this parameter it is possible to control the possible tensions generated during the manipulation of the material, avoiding cracks that are normally formed during this process of forming [17]. Although the post-pressing expansion depends mainly on the preparation, the cycle of pressing and the humidity, this reduction can be caused by the corundum. This effect is achieved because the corundum is introduced with a much smaller particle size; these particles enter in the spaces left by the clay, achieving a better densification of the same and a better control in this property that causes so many problems to the pressed products. Although the postpressurized expansion parameter has no direct relationship with the mechanical resistance [16], it exerts an influence on the mechanical development in dry piece, considering that by having a constant humidity the compactness depends on the pressure exerted and in turn affects the expansion that finally determines the accommodation of the particles 
Table II - Preparation data of the formulations.

[Tabela II - Dados de preparação das formulações.]

\begin{tabular}{ccccc}
\hline Formulation & $\begin{array}{c}\text { Drying shrinkage } \\
(\mathrm{vol} \%)\end{array}$ & $\begin{array}{c}\text { Weight loss in } \\
\text { drying }(\mathrm{wt} \%)\end{array}$ & $\begin{array}{c}\text { Dry bulk density } \\
\left(\mathrm{g} / \mathrm{cm}^{3}\right)\end{array}$ & $\begin{array}{c}\text { Post-press } \\
\text { expansion (vol\%) }\end{array}$ \\
\hline $\mathrm{M} 0\left(0 \mathrm{wt} \% \mathrm{Al}_{2} \mathrm{O}_{3}\right)$ & 0.250 & 5.407 & 1.8566 & 0.492 \\
$\mathrm{M} 5\left(5 \mathrm{wt} \% \mathrm{Al}_{2} \mathrm{O}_{3}\right)$ & 0.289 & 5.548 & 1.9372 & 0.478 \\
$\mathrm{M} 10\left(10 \mathrm{wt} \% \mathrm{Al}_{2} \mathrm{O}_{3}\right)$ & 0.338 & 5.566 & 1.9880 & 0.467 \\
$\mathrm{M} 20\left(20 \mathrm{wt} \% \mathrm{Al}_{2} \mathrm{O}_{3}\right)$ & 0.338 & 5.524 & 2.0421 & 0.457 \\
\hline
\end{tabular}

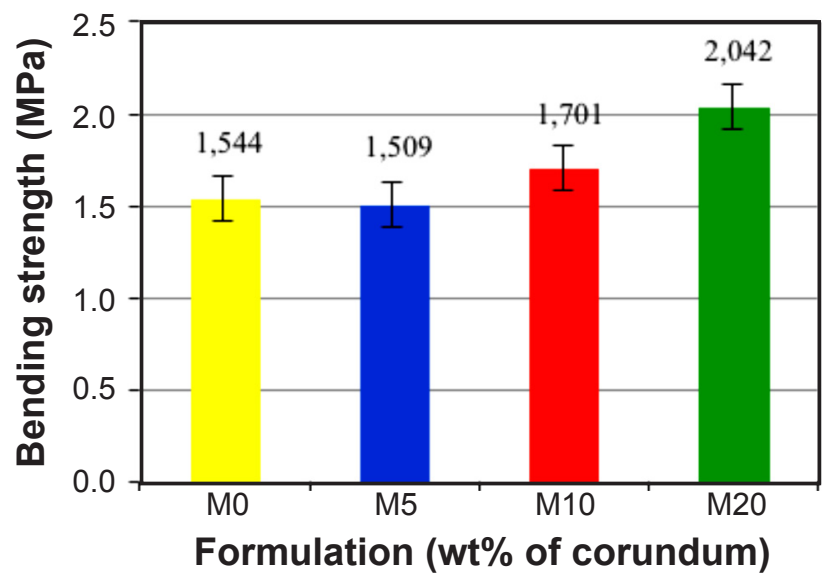

Figure 2: Mechanical resistance of dried samples.

[Figura 2: Resistência mecânica de peças secas.]

inside the product by the greater or less dissipation of this elastic energy and by having a better accommodation of the particles; internally its control is achieved, evidencing a significant increase in the dry densification of the material (Table II), generating that the values of dry strength show, in comparison with $\mathrm{M} 0$, a progressive increase of up to $32 \%$ as the corundum increases, as shown in Fig. 2.

It is known that one of the factors that generate the low mechanical strength in the dry state of a ceramic material is the poor compaction in the forming stage and the influence exerted by the weak union between their particles, but during the development of the investigation it was able to verify that this effect was minimized because the corundum entered to fill those spaces left by the clay particles at the moment of the compaction. This was supported by the increase in density by reducing these internal voids and increasing the mechanical properties. For this reason, it is mentioned that the corundum acts as a filler in the structure of the pressed pieces because as described the mechanical strength in dry pieces increased as the corundum content increased, and this increase can not be attributed only to the humidity of the powder because it remained constant and, as mentioned in [18], the pieces pressed to high humidity present higher mechanical strengths in dry state but at constant humidity it can be attributed to the influence of some additive as in this case to the corundum. Finally, it can be affirmed that these results showed that this type of materials in binary mixtures like these act as a filler in the interstices left by the clay particles, reducing voids after compaction, achieving maximum green density, increasing mechanical strength and improving properties of the material in dry condition.

Physical properties of the formulations after firing: Fig. 3 shows the densification and linear contraction values of the fired specimens. An improvement in density was observed in either case, increasing by $11.8 \%$ in M20 with respect to $\mathrm{M} 0$ at $1250{ }^{\circ} \mathrm{C}$. In such cases, the absorption of water can be reduced with increasing density and as it was observed, mechanical and tribological properties increased with an increase in corundum content, helping to generate better products with better properties as far as ceramic applications are concerned. As shown in Table II, the dry density increased as the corundum content was increased resulting in a decrease in the linear firing shrinkage (Fig.
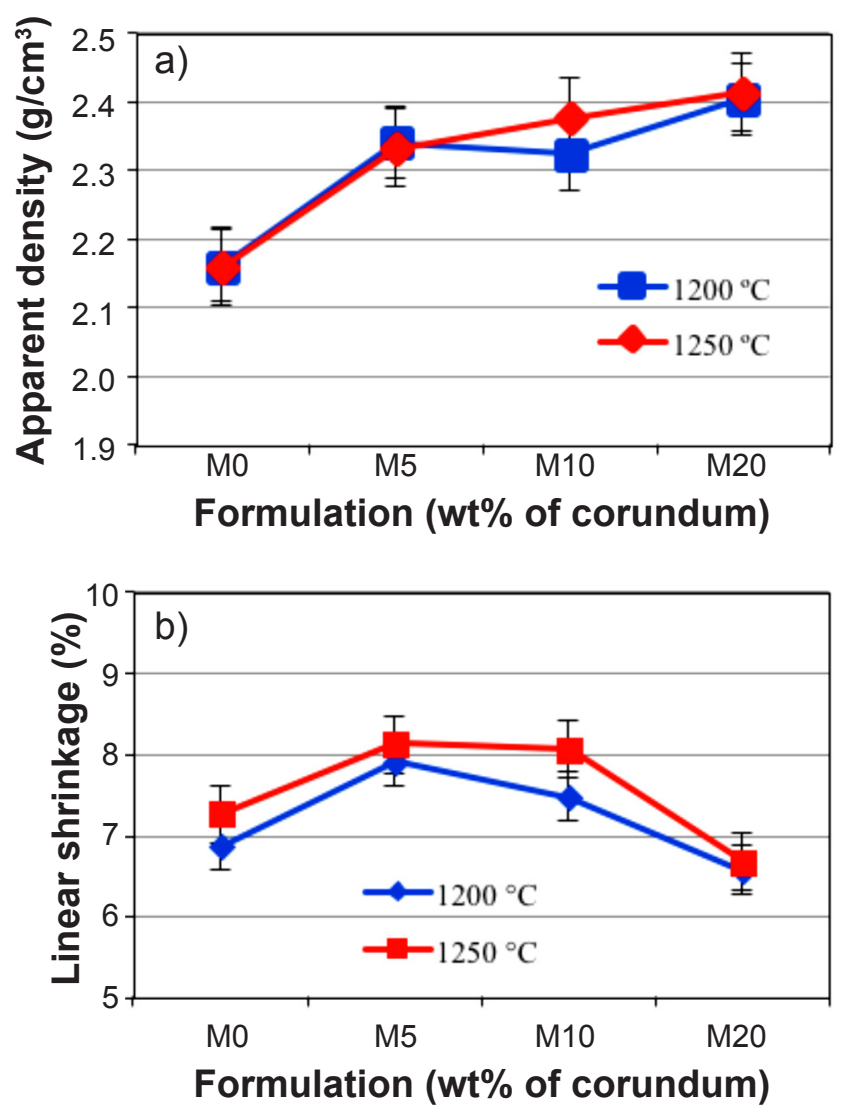

Figure 3: Apparent density (a) and linear shrinkage (b) of samples sintered at 1200 and $1250{ }^{\circ} \mathrm{C}$.

[Figura 3: Densidade aparente (a) e retração linear (b) de amostras sinterizadas a 1200 e $1250{ }^{\circ} \mathrm{C}$.] 
$3 b)$, a progressive decrease as the additive content increased. However, at a concentration of $5 \%$, the calculated values were outside the range established by M0, this is possibly due to a better behavior in the internal reactions during the firing as is the migration of gases resulting from the decomposition of carbonates and sulphates. In such cases, only up to $20 \%$ concentration a significant reduction was achieved up to $8.09 \%$ at $1250{ }^{\circ} \mathrm{C}$ and $4.38 \%$ at $1200{ }^{\circ} \mathrm{C}$; this can be attributed to the fact that the corundum generates a better rearrangement of grains, in addition to a guideline in the crystalline network that forms a solid texture and more compact, helping to generate a wider range of firing providing a better cohesion of the system and preventing in this way a deformation of the piece, which increases dimensional stability and a control in the product tensions avoiding cracks or pyroplastic deformations [19].

Structural characterization (open porosity) of the fired parts: the open porosity measured by water absorption (Fig. 4) of M0 was $8.42 \%$ and $7.97 \%$ after firing at 1200 and $1250{ }^{\circ} \mathrm{C}$, respectively. It was observed that in all the samples containing corundum the values expressed by M0 decreased, achieving a maximum reduction of up to $46 \%$ in $\mathrm{M} 10$ at $1250{ }^{\circ} \mathrm{C}$, generating in the materials an internal structure sufficiently dense to avoid the intrusion of water and increase the technological properties of this material in any technological application; this reduction is basically due to the addition of corundum, because when refractory, it influences the material especially at high temperatures, improving the consolidation mechanisms of the particles both in the solid state and in the liquid state, and controlling the formation of liquid phase in the sintering process, contributing to the decrease of this porosity, decreasing the viscosity and helping in the reduction of pore size (open and closed). In fact, if we consider the literature data of the structural characteristics in the clays when mixing them with other additives, it is emphasized that the addition of corundum equals or greatly improves any value considered, even in applications like special coatings [20]. However, it was observed that in M20 the water absorption increased but did not exceed the acceptable limit of M0 $[3,21]$. In addition, the results were more homogeneous as the percentage of corundum was increased, giving a better control in the sintering process [22]. The specimens had a smooth texture and no imperfections on the surface, achieving an improvement in their technical characteristics without affecting their aesthetic characteristics, a common problem that arises in a clay material when increasing the cooking temperature and which has been studied in previous works and other types of blends and coatings [23].

Mechanical characterization (flexural strength): to perform the mechanical characterization of fired samples, the flexural strength was determined [9]. The variation in mechanical strength is shown in Fig. 5; the results indicated that the strengths of test specimens were dependent on the amount of additive, showing increases up to $67.4 \%$ in M20 fired at $1250{ }^{\circ} \mathrm{C}$ with respect to M0. It can be affirmed that this is an important increase in relation to

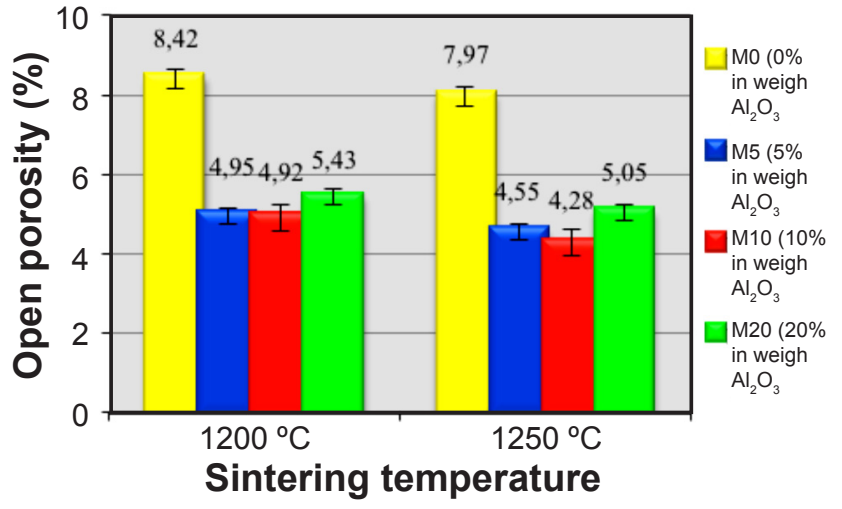

Figure 4: Open porosity of the fired pieces. [Figura 4: Porosidade aberta das peças queimadas.]

the mechanical properties, since it has been studied that among the most frequent problems in a cooking cycle of a ceramic material is the passage from the plastic state to the elastic state, which normally occurs between 550 and $625{ }^{\circ} \mathrm{C}$; it is in this point where the internal structure of the material generates differences of tensions that can get to crack and/or deform the product if a gradual change is not made, generating the decrease in the resistance of the same. For this reason, the addition of corundum helps to improve this change of state, reducing internal tensions and reducing its technical problems, which is demonstrated by the values shown in Fig. 5, where the addition of corundum to clay minerals exerts a tangible influence improving the resistance to the permanent deformation and increasing its degree of elasticity; it can be affirmed that the increase of the corundum improves mechanical properties; this could be due to several causes: first, the reduction of its index of pressability influences the reduction of cracks (main defect of breaks); second, the corundum helps to seal pores and other irregularities which influences in the presented low porosity; and mainly (third cause) the increase is due to the high density in both dry and cooked state, effect caused by the addition of corundum [24, 25]. Strength was observed

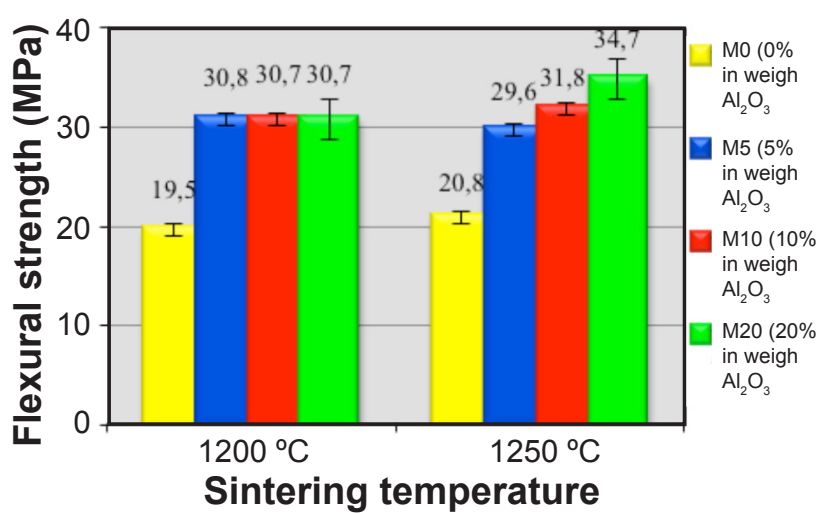

Figure 5: Effect of flexural strength as a function of sintering temperature.

[Figura 5: Efeito da resistência à flexão em função da temperatura de sinterização.] 
to increase from 19 to $30 \mathrm{MPa}$ at $1200{ }^{\circ} \mathrm{C}$ and from 20 to $34 \mathrm{MPa}$ at $1250{ }^{\circ} \mathrm{C}$ when the corundum contents increased from 5 to $20 \mathrm{wt} \%$. Normally the addition of additives to the clay is not recommended due to its negative effects on the final properties because this type of materials not only reduces the contact between the materials preventing their mutual reaction but also the increase in the percentages of these decreases the amount of clay in the specimens affecting it negatively [26]. This is an important aspect because the high addition of corundum does not diminish properties but on the contrary, it increases, the same being able to be used in other industrial applications different from the traditional ones [27].

Influence of the addition of corundum on abrasion wear protection: the tribological characterization was developed by means of the deep abrasion test with the objective of knowing the resistance against mechanical, physical or external natural aggressions. Fig. 6 shows the obtained results, where the evolution of the wear (volume removed of material) in the surface of the specimens was compared; in the case of M0 an increase of the volume removed in the two firing temperatures was observed indicating that the material is intrinsically affected in its structure [28]. Although the abrasion resistance is related to the open porosity of the material, this characteristic is also affected by the texture and surface adhesion of the product indicating that the increase in temperature superficially affects the material by weakening it structurally [29]. This wear was minimized with the addition of corundum; it was observed that increasing the additive reduced the volume removed mainly in M20 fired at $1250{ }^{\circ} \mathrm{C}$, which can be explained to the fact that the corundum has a high hardness and therefore is a material which is resistant to wear, an effect that is effectively developed in the material and is evidenced with the decrease of up to $33.9 \%$ at 1200 ${ }^{\circ} \mathrm{C}$ and $51.5 \%$ at $1250{ }^{\circ} \mathrm{C}$. Another factor that is evidenced and that is a significant contribution to the protection of the products is that in spite of the increase in the porosity, the addition of corundum can correct this fault because, as shown in Fig. 4, the formulation M20 presented an increase in this property and this was not inconvenient to protect it from the abrasion effect. In any case, the addition of corundum to the clay favored the increase of the resistance to the wear acting as a protective agent of clayey materials, which is a significant effect in industrial processes where the abrasion by external agents is high and attack with greater force. This feature together with the improvement of the other properties evidenced that the ceramic sector can be a receiver of this type of waste, making incorporations in relatively high percentages for these processes. This is probably due to the fact that the addition of corundum increases the mullite fraction, which was verified by the preliminary analyzes of X-ray diffraction and scanning electron microscopy, results that will be exposed in a future investigation, and that may be related to the increase on mechanical strength and wear resistance [30].

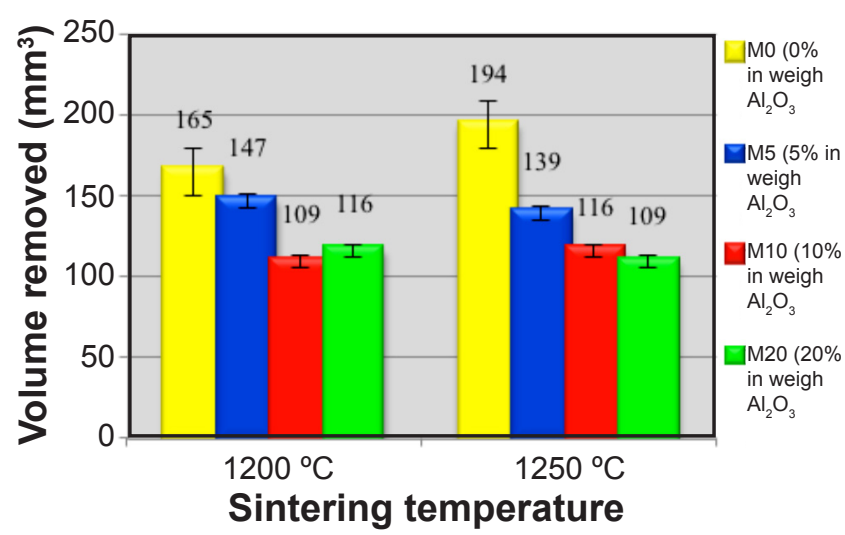

Figure 6: Resistance to deep abrasion (ISO 10545-6). [Figura 6: Resistência à abrasão profunda (ISO 10545-6).]

\section{CONCLUSIONS}

In this work, the structural, mechanical and tribological response of a red clay from the region of Norte de Santander when being mixed with corundum was evaluated; from the results obtained the following conclusions were deduced. It was evidenced that the mixture with corundum exerted an improvement in the properties of the clay,increasing them; this is an important aspect considering that normally the addition of additives to the clay is not advisable due to its negative effects on the final properties, mainly when working with high firing temperatures. The coefficient of thermal expansion decreased by $5.5 \%$ and even by $9.6 \%$, with the additions of 5 and $20 \mathrm{wt} \%$ of corundum, respectively. The water absorption of the samples was in the range of 4.92 to $5.43 \%$ for the samples fired at $1200{ }^{\circ} \mathrm{C}$ and 4.28 to $5.05 \%$ for the samples fired at $1250{ }^{\circ} \mathrm{C}$, achieving a decrease of up to $46 \%$. It was observed that mechanical strength increased from 19 to 30 $\mathrm{MPa}$ at $1200{ }^{\circ} \mathrm{C}$ and from 20 to $34 \mathrm{MPa}$ at $1250{ }^{\circ} \mathrm{C}$. This way, an addition of corundum of $5 \%$ and $20 \%$ by weight, sintering at $1250{ }^{\circ} \mathrm{C}$, increased the mechanical resistance regarding the starting clay material (M0) from $42 \%$ to $67 \%$, respectively. The wear resistance achieved increase by $33.9 \%$ and $51.5 \%$ at 1200 and $1250{ }^{\circ} \mathrm{C}$, respectively, and the clay material could be used in other industrial areas that are exposed to various environmental or physical factors of great deterioration, as for example in coatings for high-temperature furnaces, in coatings of tools for taladar or milling, as well as in own technological applications. Finally, it is possible to emphasize that the mixture with $20 \mathrm{wt} \%$ of additive was the one that showed in general better results in comparison with the data from the other mixtures, without ruling out that products with highly improved properties were obtained without modifying the surface texture of the material at high temperatures and which can be used in any extreme environment as well as in other advanced technological applications

\section{ACKNOWLEDGMENT}

The authors thank the CIMAC Ceramic Materials 
Research Center of the Francisco de Paula Santander University of Cúcuta-Colombia for the support provided for the realization of the tests.

\section{REFERENCES}

[1] G. Benveniste, C. Gazulla, P. Fullana, I. Celades, T. Ros, V. Zaera, B. Godes, Inf. Constr. 63, 522 (2011) 71.

[2] W. Chih-Huang, L. Deng-Fong, C. Pen-Chi, Adv. Environ. Res. 7 (2003) 679.

[3] L. Cely Illera, Rev. Fac. Ing. Univ. Antioquía 80 (2016) 31.

[4] A. Safeer, I. Yaseen, M. Raz, Bol. Soc. Esp. Ceram. Vidr. 56 (2017) 131.

[5] ISO 8486-1, "Bonded abrasives: determination and designation of grain size distribution, part 1: macrogrits F4 to F220" (2011).

[6] J.F. Gelves, R. Monroy, J. Sánchez, R.P. Ramírez, Bol. Soc. Esp. Ceram. Vidr. 52, 1 (2013) 48.

[7] Am. Soc. Test. Mater., ASTM C326-03: "Standard test method for drying and firing shrinkages of ceramic whiteware clays" (2011).

[8] ISO 10545-3, "Ceramic tiles - part 3: determination of water absorption, apparent porosity, apparent relative" (1995).

[9] ISO 10545-4, "Ceramic tiles - part 4: determination of modulus of rupture and breaking strength" (1994).

[10] ISO 10545-6, "Ceramic tiles - part 6: determination of resistance to deep abrasion for unglazed tiles" (1995).

[11] C. Hoffmann, E.F.U. Carvalho, H.G. Riella, A.M. Bernardin, in: Congr. Mund. Calid. Azul. Pavim. Cerám., Castellon (2008) 149.

[12] N.U. Kockal, Bol. Soc. Esp. Ceram. Vidr. 51, 5 (2012) 297.

[13] J.L. Amoros, A. Belda, M.J. Orts, A. Escardino, Bol. Soc. Esp. Ceram. Vidr. 31, 2 (1992) 109.

[14] S. de Aza Pendas, Bol. Soc. Esp. Ceram. Vidr. 3, 4 (1964) 395.
[15] A. Escardino Benlloch, J.L. Amores Albaro, J.E. Enrique Navarro, Bol. Soc. Esp. Ceram. Vidr. 20, 1 (1981) 17.

[16] R. Galindo Renau, Prensas, moldes y prensado en la fabricación de baldosas cerámicas, Vol. 1, Macer, Italia (2008).

[17] J.L. Amoros, A. Moreno, M.J. Orts, A. Escardino, Bol. Soc. Esp. Ceram. Vidr. 29, 3 (1990) 151.

[18] J.L. Amorós, C. Felíu, E. Ginés, J.V. Agramunt, Bernardin, in: Congr. Mund. Calid. Azul. Pavim. Cerám., Castellon (1996) 153.

[19] G.-H. Mahdavi, S. Arjmandnia, M. Fouladkar, in: Congr. Mund. Calid. Azul. Pavim. Cerám., Castellon (2016) 1.

[20] M. Araque-Pabón, G. Peña-Rodríguez, F. VargasGalvis, TecnoLógicas 18, 35 (2015) 125.

[21] S.N. Monteiro, J. Alexandre, J.I. Margem, R. Sánchez, C.M. Vieira, Constr. Build. Mater. 22 (2008) 1281.

[22] L. Ven-Gen, Y. Ting-Hao, Mater. Sci. Eng. A. 485 (2008) 5 .

[23] J. Gilabert, E. Zumaquero, C. Machí, J. Toledo, M.P. Gómez-Tena, Bol. Soc. Esp. Ceram. Vidr. 54, 5 (2015) 209.

[24] N. Afanador García, G. Guerrero Gómez, R. Monroy Sepúlveda, Cienc. Ing. Neogranad. 22, 1 (2012) 43.

[25] J.F. Gelves Diaz, J. Sánchez Molina, G. Peña Rodríguez, Respuestas 14, 2 (2009) 32.

[26] S.M. Rozo Rincón, J. Sánchez Molina, D.C. Álvarez, Cienc. Ing. Neogranad. 24, 1 (2014) 67.

[27] ISO 13006, "Ceramic tiles - definitions, classification, characteristics and marking" (1998).

[28] A.L. Abitante, C.P. Bergmann, J.L. Ribeiro, Eng. Civ. 29 (2007) 71.

[29] L. Esposito, A. Tucci, Bol. Soc. Esp. Ceram. Vidr. 39, 1 (2000) 165.

[30] S. Ghasemi-Kahrizsangi, H.G. Dehsheikh, M. Boroujerdnia, Bol. Soc. Esp. Ceram. Vidr. 56 (2017) 83.

(Rec. 17/07/2017, Rev. 18/10/2017, 26/12/2017, Ac. $14 / 01 / 2018)$ 